\title{
Ascidiacea (Chordata, Tunicata) from Uruguay (SW Atlantic): checklist and zoogeographic considerations
}

\author{
Fabrizio SCARABINO ${ }^{1}$, Tamara MAGGIONI ${ }^{2 *}$, Anabela TAVERNA ${ }^{3}$, Cristian LAGGER ${ }^{4}$, \\ Evangelina SCHWINDT ${ }^{5}$, Lobo ORENSANZ ${ }^{6 * *}$, Guzmán LÓPEZ ${ }^{7}$, Leonardo ORTEGA ${ }^{8}$, Felipe \\ GARCÍA-RODRÍGUEZ ${ }^{9,11} \&$ Marcos TATIÁN ${ }^{10}$
}

\begin{abstract}
${ }^{1,9}$ Centro Universitario Regional del Este - CURE, Universidad de la República, Ruta 9 intersección Ruta 15, Rocha, Uruguay. ${ }^{1}$ Museo Nacional de Historia Natural, C. C. 399, C. P. 11.000, Montevideo, Uruguay. ${ }^{2,3,4,10}$ Consejo Nacional de Investigaciones Científicas y Técnicas (CONICET), Instituto de Diversidad y Ecología Animal (IDEA), Av. Vélez Sarsfield 299, 5000 Córdoba, Argentina. ${ }^{10}$ Ecología Marina, Facultad de Ciencias Exactas, Físicas y Naturales, Universidad Nacional de Córdoba, Av. Vélez Sarsfield 299 (5000). Córdoba, Argentina. ${ }^{5}$ Instituto de Biología de Organismos Marinos, CONICET, Bv. A. Brown 2915, Puerto Madryn, Chubut, Argentina. ${ }^{6,7}$ Dirección Nacional de Recursos Acuáticos, Constituyente 1497, Montevideo (11200), Uruguay. ${ }^{11}$ Programa de Pós-Graduação em Oceanografia Física, Química e Geológica, Instituto de Oceanografia, Universidade Federal do Rio Grande, Av. Itália, km 8, Cx.P. 474, 96201-900, Rio Grande, RS, Brazil. * Corresponding author: tamaramaggioni@gmail.com.** Deceased.
\end{abstract}

\begin{abstract}
The diversity of ascidians from the Southwestern Atlantic between $30^{\circ} \mathrm{S}$ and $40^{\circ} \mathrm{S}$ (southern Brazil, Uruguay and northern Argentina) remains as one of the poorest known of the West Atlantic. The objective of this work is to compile, analyze and discuss all published records of ascidians from Uruguay. They show the historical relevance of the studies performed by Herdman, Monniot F. and Monniot C. on ascidians collected at deep-sea stations by the HMS Challenger and the RV Atlantis II in the Argentine Basin. Total literature records include 38 ascidian species which are enumerated here for the first time. On the basis of the current knowledge, the ascidian fauna of Uruguayan waters encompasses: a) shallow-water species with temperate distribution ( $3 \mathrm{spp}$.); b) shelf and deep-sea species with Antarctic and Sub-Antarctic distribution (13 spp.); c) deep-sea species until now only collected off Río de La Plata (11 spp.); d) deep-sea species displaying a wide distribution (11 spp.). Only nine species have been recorded for the continental shelf; the remaining species were collected either from the slope (21) or the abyssal plain (5) or both deep-sea zones (3). Future research should be directed to record coastline and shelf species, assess the presence of exotic elements, and re-describe enigmatic species first described by Herdman $(1882,1886)$.
\end{abstract}

Key words: Diversity, deep-sea, Argentine Basin, taxonomy, biogeography

Resumen: Ascidiacea (Chordata, Tunicata) de Uruguay (Atlántico SO): checklist y consideraciones zoogeográficas. La diversidad de ascidias del Atlántico Sudoccidental entre $30^{\circ} \mathrm{S}$ y $40^{\circ} \mathrm{S}$ (sur de Brasil, Uruguay y norte de Argentina) sigue siendo una de las más escasamente conocidas del Atlántico occidental. El objetivo de este trabajo es compilar, analizar y discutir todos los registros publicados de ascidias de Uruguay. Muestran la relevancia histórica de los estudios realizados por Herdman, Monniot F. y Monniot C. sobre las ascidias recogidas por el HMS Challenger y el RV Atlantis II en la Cuenca Argentina. Los registros de la literatura incluyen 38 especies de ascidias que se enumeran aquí por primera vez. Sobre la base de los conocimientos actuales, la fauna de ascidias de aguas uruguayas comprende: a) especies de aguas someras con distribución templada (3 especies); b) especies de plataforma y de aguas profundas con distribución Antártica y Sub-Antártica (13 especies); c) especies de aguas profundas hasta ahora sólo se recolectaron en la desembocadura del Río de La Plata (11 especies); d) especies de aguas profundas que muestran una amplia distribución (11 especies). Sólo se han registrado nueve especies para la plataforma continental; las especies restantes se recolectaron en el talud (21), en la planicie abisal (5) o en ambas zonas de aguas profundas (3). Las investigaciones futuras deben orientarse a registrar las especies costeras y de plataforma, evaluar la presencia de especies exóticas y volver a describir especies enigmáticas descritas por primera vez por Herdman $(1882,1886)$.

Palabras clave: Diversidad, ambientes marinos profundos, Cuenca Argentina, taxonomía, biogeografía 


\section{INTRODUCTION}

Ascidians (Chordata, Tunicata) represent diverse and abundant components of benthic communities. They are present in all kinds of marine environments, with wide geographic and bathymetric distributions. Shenkar \& Swalla (2011) estimated the global ascidian richness in about 3000 species, stressing the necessity of studies in areas still understudied and undersampled, such as the SW Atlantic. Investigations performed in the area in recent years have yielded new species (Lagger \& Tatián 2013; Rocha et al. 2015) and further new data from redescriptions of poorly known ones (e.g. Maggioni et al. 2016). In the SW Atlantic, reports of invasive and cryptogenic species have also increased (Tatián et al. 2010; Schwindt et al. 2014; Skinner et al. 2016).

Ascidian diversity studies in this region have been mainly performed in the Patagonian shelf, South Argentina (e.g. Van Name 1945; Diehl 1977; Lagger \& Tatián 2013; Taverna et al. 2018), and Brazil (e.g. Rocha \& Costa 2005; Bonnet \& Rocha 2011; Moreno et al. 2014). Rocha et al. (2012) presented a list of 461 species from shallow waters comprising the entire Atlantic Ocean. Despite these studies, the diversity of ascidians from the SW Atlantic coast between $30^{\circ} \mathrm{S}$ and $40^{\circ} \mathrm{S}$ (southern Brazil, Uruguay and northern Argentina) still remains comparatively less described, being the poorest known area in the region (Moreno et al. 2014).

In particular, faunistic knowledge of ascidians from Uruguayan waters mainly comes from the works of Herdman (1880; 1881a; 1881b; 1882; 1886), Monniot C. \& Monniot F. (1985a) and Monniot F. \& Monniot C. (1976), who respectively reported the material collected by the HMS Challenger (1872-1876) and RV Atlantis II (1971) in the Argentine Basin. Therefore, most of these species come from the deep-sea; inner shelf ascidians from Uruguay have been poorly recorded. In fact, all six references summarized by Scarabino (2006) (i.e., Millar 1969; Juanicó \& Rodríguez-Moyano 1976; Milstein et al. 1976; Cachés 1980; Obenat et al. 2001; Orensanz et al. 2002) for the inner shelf ascidian fauna correspond to unidentified or poorly documented records. Thus, as a first step for further knowledge of the scarcely known ascidian fauna of Uruguay, the aim of this work is to compile, analyze and discuss all the published records of ascidians from Uruguay as a basis for future research. The latter includes the analysis of ascidian aragonitic spicules as potential paleoecological indicators in the Uruguayan shelf (see e.g. Toledo et al. 2007; Sagular 2009; Shenkar \& Swalla 2011; Sagular et al. 2017).

\section{MATERIALS AND METHODS}

Ascidian records come from the Uruguayan coast and the Uruguayan Exclusive Economic Zone (URY EEZ, Figure 1), including shallow coastal areas, outer shelf, slope and abyssal plain. The last two mentioned areas belong to the Argentine Basin. A complex oceanographic system develops in the area, involving the confluence of warm and cold marine currents and the freshwater input of La Plata River. A general oceanographic, geomorphological and sedimentological outline of the zone can be found in Scarabino et al. (2016) and Hanebuth et al. (2018).

An inventory of species was compiled from papers, books chapters, meeting abstracts and theses.

The current status of the all species was verified through literature and the World Register of Marine Species webpage (www.marinespecies. org). The order of the species list followed the criteria adopted by the latter resource (Shenkar et al. 2018a).

For each species the following information is provided: 1) original combination and reference eventually followed by references on the synonymy (when extensive), 2) geographic distribution, 3) references and bathymetric distribution in Uruguayan waters and 4) observations, that may include the reference(s) that cited the species in its current combination, comments and/ or discussions on the status of the species or the Uruguayan records.

References regarding the geographic distribution of littoral species include: a) general/major revisions containing comprehensive treatment of these and/or b) works extending considerably (i.e. thousands of $\mathrm{km}$ ) the range of a given species. In the case of deep-sea species, we considered all available references.

Only one record (station 242 of the cruise 60 of the RV Atlantis II) that is located some miles off this zone is included here considering the imminent enlargement of the UEEZ. Station 320 of the HMS Challenger falls exactly on the maritime boundary between Argentina and Uruguay and, therefore, such species are considered as part of the faunistic inventory of both countries. On the other hand, one species recorded as collected "off Montevideo" (i.e. Styela schmitti Van Name, 1945, 


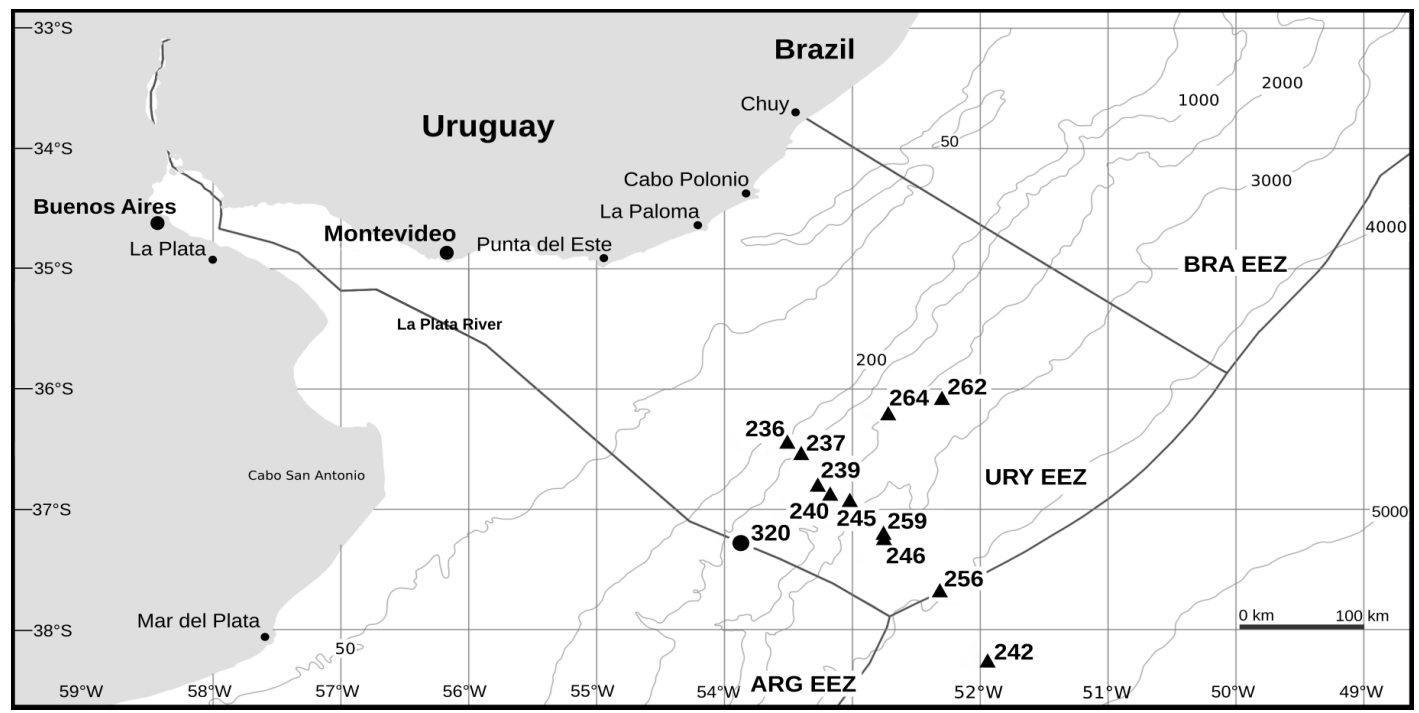

Fig. 1. Uruguayan Exclusive Economic Zone (URY EEZ), indicating the position of the stations of HMS Challenger (circles) and RV Atlantis II (triangles).

see also Millar 1960 and Monniot C. \& Monniot F. 1983 who also indicated "off Montevideo" or "off Uruguay") was actually collected in shallow waters (at ca. $20 \mathrm{~m}$ ) off Cabo San Antonio, Buenos Aires Province, Argentina ( $36^{\circ} 42^{\prime} \mathrm{S}, 53^{\circ} 23^{\prime} \mathrm{W}$ ) and therefore it is not included here. In fact, that is also the type locality of Molgula platana Van Name, 1945 (Albatross station 2764), which was never referred from Uruguay. Full data and mapping of the stations of HMS Challenger and RV Atlantis II from Uruguayan waters are provided (Table 1, Figure 1).

The bathymetric zonation is considered as follows: shelf $(0-200 \mathrm{~m})$, upper slope $(200-1500$ $\mathrm{m})$, lower slope (1500-3000 m) and abyssal plain (3000-5500 m).

\section{RESULTS}

Literature records totalized 38 ascidian species distributed throughout the assessed area (Table 2). Species belong to 29 genera distributed in 13 families, with three families being most speciose: Polyclinidae (5 species), Styelidae (11) and Molgulidae (7).

Order APLOUSOBRANCHIA Lahille, 1886

Family POLYCLINIDAE Milne Edwards, 1841

\section{Genus Aplidium Savigny, 1816}

\section{Aplidium effrenatum (Herdman, 1886)}

Psammaplidium effrenatum Herdman, 1886: 241, pl. 32, figs. 6-7.

Geographic distribution: only known from the type locality: Argentine Basin (Uruguay-Argentina).

References and bathymetric distribution in Uruguayan waters: Herdman (1886: 241): $1097 \mathrm{~m}$ (HMS Challenger, st. 320).

Observations: Hartmeyer (1907-1911) and Van Name (1945) included this species in the genus Aplidium.

\section{Aplidium fuegiense Cunningham, 1871}

Aplidium fuegiense Cunningham, 1871: 66.

For synonymy see Van Name (1945: 43) and Monniot C. \& Monniot F. (1983: 16).

Geographic distribution: Antarctic and Sub-Antarctic regions (Kerguelen, Crozet, South Georgia; Antarctic Peninsula); SE Pacific up to $27^{\circ} \mathrm{S}$; SW Pacific (Auckland Island)?; Magellan Strait; Patagonian shelf (Millar 1960; Kott 1969; Kott 1971; Monniot C. \& Monniot F. 1983; Sanamyan 
\& Schories 2003; Varela 2007; Lagger et al. 2009; Sanamyan et al. 2010).

References and bathymetric distribution in Uruguayan waters: Barranguet (1988): not detailed, between 37-110 m; Varela (2007); $134 \mathrm{~m}$ (73 fathoms). Records not yet substantiated (mentioned in abstract and thesis).

\section{Aplidium variabile (Herdman, 1886)}

Amaroucium variabile Herdman, 1886: 216, pl. 29, figs. 7-12

Geographic distribution: Sub-Antarctic islands (Kerguelen and South Georgia); SW Pacific (New Zealand); SE Pacific; Magellan Strait, Patagonian Shelf (Millar 1960; Kott 1969; 1971 and references therein; Monniot C. \& Monniot F. 1983 and references therein; Sanamyan \& Schories 2003; Varela 2007; Lagger et al. 2009).

References and bathymetric distribution in Uruguayan waters: Barranguet (1988): not detailed, between 37-110 m. Record not yet substantiated (mentioned in abstract).

\section{Aplidium flavum (Herdman, 1886) nomen dubium}

Psammaplidium flavum Herdman, 1886: 249: pl. 32, fig.11-13.

Geographic distribution: only known from the type locality: Argentine Basin (Uruguay-Argentina).

References and bathymetric distribution in Uruguayan waters: Herdman (1886: 249-250): 1097 m (HMS Challenger, st. 320).

Observations: Van Name (1945: 445) indicates that the original description of this species is incomplete and thus fails to permit a correct classification. Rocha and Lambert (pers. com. 2013) agree with Van Name's comments and indicate this species as a nomen dubium until the type and especially topotypic material is re/described. This is not Aplidium flavum Huitfeld-Kaas, 1896, a synonym of Aplidium glabrum (Verrill, 1871) (Shenkar et al. 2018b).

\section{Aplidium sp.}

Observations: Monniot F. \& Monniot C. (1976:
630-631) and Monniot C. \& Monniot F. (1985a: 8) recorded undeterminable material (much contracted isolated individuals, not colonies) of Aplidium sp. from RV Atlantis II, cruise 60, sts. 237, 245, 246 and 259 collected between 993 and $3343 \mathrm{~m}$. We did not include this record in the total count for the area nor in Table 1 because it is impossible to assess whether it corresponds to one of the previous Aplidium species or to a different one.

Genus Synoicum Phipps, 1774

Synoicum molle (Herdman, 1886)

Polyclinum molle Herdman, 1886: 194, pl. 25, fig. 7-9, not Rocha and Costa 2005: 59, figs. 2-4.

Synoicum molle Van Name 1945: 84, fig. 20, Maggioni et al. 2016: 181-185, fig. 2-4.

Geographic distribution: Argentine Basin (Uruguay-Argentina), off Río de La Plata and Buenos Aires Province (Argentina).

References and bathymetric distribution in the area: Herdman (1886: 194-195): 1097 m.

Observations: collected at HMS Challenger st. 320 , which is the type locality of this species (Herdman 1886: 194-195) and recently found and redescribed off Mar del Plata at $308 \mathrm{~m}$ depth, i.e., relatively close to the type locality (Maggioni et al. 2016: 181-185). Van Name (1945) included this species tentatively in the genus Synoicum, a denomination that Maggioni et al. (2016) confirmed.

Aplidium incrustans Herdman 1886, also described from material of the HMS Challenger st. 320 , has been referred by Van Name (1945) as a possible junior synonym of $S$. molle although stating that both species are poorly characterized. Maggioni et al. (2016) rejected this synonymy based on a detailed comparison of branchial sacs. They propose to maintain both entities as separate species. This is not Psammaplidium incrustans Herdman 1891 with type locality in Port Stephens, New South Wales, Australia, a junior synonym of Aplidium solidum (Herdman 1891) (Kott 2005).

Rocha \& Costa (2005) described Polyclinum molle $\mathrm{n}$. sp. from shallow-waters of Brazil but this name is preoccupied by Polyclinum molle Herdman, 1886. Hence, the former is not valid. 
Table 1. Stations of the HMS Challenger and RV Atlantis II mentioned in the text.

\begin{tabular}{ccc}
\hline Station & Latitude; Longitude & Depth $(\mathrm{m})$ \\
\hline HMS Challenger (February 1876) & \\
\hline Station 320 & $37^{\circ} 17^{\prime} \mathrm{S} ; 53^{\circ} 52^{\prime} \mathrm{W}$ & 1097 \\
\hline RV Atlantis, cruise 60 (March 1971) & $497-518$ \\
\hline Station 236 & $36^{\circ} 27^{\prime} \mathrm{S} ; 53^{\circ} 31^{\prime} \mathrm{W}-$ & $993-1011$ \\
Station 237 & $36^{\circ} 28.1^{\prime} \mathrm{S} ; 53^{\circ} 32.3^{\prime} \mathrm{W}$ & $1661-1679$ \\
Station 239 & $36^{\circ} 32.6^{\prime} \mathrm{S} ; 53^{\circ} 23.0^{\prime} \mathrm{W}$ & $2195-2323$ \\
Station 240 & $36^{\circ} 49^{\prime} \mathrm{S} ; 53^{\circ} 15.4^{\prime} \mathrm{W}$ & 4382 \\
Station 242 & $36^{\circ} 53.4^{\prime} \mathrm{S} ; 53^{\circ} 10.2^{\prime} \mathrm{W}$ & 2707 \\
Station 245 & $38^{\circ} 16.9^{\prime} \mathrm{S} ; 51^{\circ} 56.1^{\prime} \mathrm{W}$ & 3343 \\
Station 246 & $36^{\circ} 55.7^{\prime} \mathrm{S} ; 53^{\circ} 01.4^{\prime} \mathrm{W}$ & 2440 \\
Station 256 & $37^{\circ} 15.1^{\prime} \mathrm{S} ; 52^{\circ} 45^{\prime} \mathrm{W}$ & $3906-3917$ \\
Station 259 & $37^{\circ} 40.9^{\prime} \mathrm{S} ; 52^{\circ} 19.3^{\prime} \mathrm{W}$ & 3305 \\
Station 262 & $37^{\circ} 13.3^{\prime} \mathrm{S} ; 52^{\circ} 45^{\prime} \mathrm{W}$ & $36^{\circ} 05.2^{\prime} \mathrm{S} ; 52^{\circ} 17.9^{\prime} \mathrm{W}$ \\
\hline
\end{tabular}

Family HOLOZOIDAE Berrill, 1950

Genus Distaplia Della Valle, 1881 Distaplia cylindrica (Lesson, 1830)

Holozoa cylindrica Lesson, 1830: 439.

For synonymy see Kott (1969: 29) and Monniot C. \& Monniot F. (1983: 36).

Geographic distribution: circumpolar; Magellanic area and Patagonian Shelf (Kott 1969; 1971 and references therein; Monniot C. \& Monniot F. 1983 and references therein; Sanamyan \& Schories 2003; Monniot et al. 2011).

References and bathymetric distribution in Uruguayan waters: Barranguet (1988): not detailed, between 37-110 m. Record not yet substantiated (mentioned in abstract).

Genus Sycozoa Lesson, 1830

Sycozoa sigillinoides Lesson, 1830
Sycozoa sigillinoides Lesson 1830: 436.

For synonymy see Kott (1969: 26).

Geographic distribution: circumpolar and SubAntarctic distribution up to $34^{\circ} \mathrm{S}$ in Southwestern Atlantic (Van Name 1945; Millar 1960; 1970; Kott 1969; 1971; Monniot C. \& Monniot F. 1983; Tatián et al. 1998; Kott 2006; Monniot et al. 2011). Isolated heads in plankton samples collected in the tropical Atlantic (Michaelsen 1907) and Pacific Ocean (Michaelsen 1924).

References and bathymetric distribution in Uruguayan waters: Juanicó \& Rodríguez-Moyano (1976, as Sycozoa umbellata): 35-50 m; Millar (1970): $70 \mathrm{~m}$.

Observations: Barranguet (1988) mentioned "some heads of Sycozoa, probably S. sigillinoides" for the Uruguayan shelf (depth not detailed, between 37 and $110 \mathrm{~m}$ ). 
Table 2. Summary of the species of Ascidiacea recorded at Uruguayan waters. WD: widely distributed deep-sea species; RDLP: only off Río de La Plata deep-sea species; ANT-SANT: Antarctic and Sub-Antarctic shelf and deep-sea species; TEMP: temperate-distribution species; ABY: abyssal plain; LOW SLOPE: lower slope (1500-3000 m); UPPER SLOPE: upper slope (200-1500 m); SHELF: shelf; *: poorly recorded in Uruguay; **: poorly known species.

\begin{tabular}{|c|c|c|c|c|c|c|c|c|}
\hline SPECIES & 岳 & 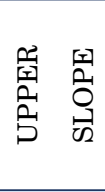 & 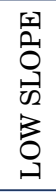 & 䆓 & $\sum_{\text {空 }}^{p}$ & $\begin{array}{l}\text { 至 } \\
\text { 希 } \\
\text { 告 } \\
\text { 岁 }\end{array}$ & 穴 & 方 \\
\hline Aplidium effrenatum ${ }^{* *}$ & & $\mathbf{x}$ & & & & & $\mathbf{x}$ & \\
\hline Aplidium fuegiense* & $\mathbf{x}$ & & & & & $\mathbf{x}$ & & \\
\hline Aplidium variabile* & $\mathbf{x}$ & & & & & $\mathbf{x}$ & & \\
\hline Aplidium flavum $^{* *}$ & & $\mathbf{x}$ & & & & & $\mathbf{x}$ & \\
\hline Synoicum molle & & $\mathbf{x}$ & & & & & $\mathbf{x}$ & \\
\hline Distaplia cylindrica* & $\mathbf{x}$ & & & & & $\mathbf{x}$ & & \\
\hline Sycozoa sigillinoides & $\mathbf{x}$ & & & & & $\mathbf{x}$ & & \\
\hline Didemnum studeri & $\mathbf{x}$ & & & & & $\mathbf{x}$ & & \\
\hline Didemnum tenue *** $^{*}$ & & $\mathbf{x}$ & & & & & $\mathbf{x}$ & \\
\hline Coelocormus huxleyi** & & $\mathbf{x}$ & & & & & $\mathbf{x}$ & \\
\hline Pseudodiazona abyssa & & $\mathbf{x}$ & & & & & & $\mathbf{x}$ \\
\hline Araneum sigma & & & $\mathbf{x}$ & & & & & $\mathbf{x}$ \\
\hline Agnezia celtica & & & & $\mathbf{x}$ & & & & $\mathbf{x}$ \\
\hline Adagnesia charcoti & & & $\mathbf{x}$ & & & & & $\mathbf{x}$ \\
\hline Caenagnesia complementa & & & $\mathbf{x}$ & & & & $\mathbf{x}$ & \\
\hline Ascidia meridionalis & & $\mathbf{x}$ & & & & $\mathbf{x}$ & & \\
\hline Corella sp.**** & $\mathbf{x}$ & & & & $\mathbf{x}$ & & & \\
\hline Hypobythius moseleyi ${ }^{* *}$ & & $\mathbf{x}$ & & & & & $\mathbf{x}$ & \\
\hline Octacnemus ingolfi & & & $\mathbf{x}$ & & & & & $\mathbf{x}$ \\
\hline Styela chaini & & & $\mathbf{x}$ & & & & & $\mathbf{x}$ \\
\hline Styela flava** & & $\mathbf{x}$ & & & & & $\mathbf{x}$ & \\
\hline Styela glans & & $\mathbf{x}$ & & & & $\mathbf{x}$ & & \\
\hline Styela plicata* & $\mathbf{x}$ & & & & $\mathbf{x}$ & & & \\
\hline Styela squamosa & & $\mathbf{x}$ & & & & $\mathbf{x}$ & & \\
\hline Dicarpa spinifera & & & & $\mathbf{x}$ & & & $\mathbf{x}$ & \\
\hline Polycarpa aspera & & $\mathbf{x}$ & & & & & $\mathbf{x}$ & \\
\hline Polycarpa pseudoalbatrossi & & & $\mathbf{x}$ & $\mathbf{x}$ & & & & $\mathbf{x}$ \\
\hline Bathystyeloides enderbyanus & & & $\mathbf{x}$ & & & & & $\mathbf{x}$ \\
\hline Cnemidocarpa bathyphila & & & $\mathbf{x}$ & & & & & $\mathbf{x}$ \\
\hline Botryllus schlosseri* & $\mathbf{x}$ & & & & $\mathbf{x}$ & & & \\
\hline Culeolus anonymus & & & & $\mathbf{x}$ & & $\mathbf{x}$ & & \\
\hline Minipera tacita & & & & $\mathbf{x}$ & & & $\mathbf{x}$ & \\
\hline Protomolgula bythia & & & $\mathbf{x}$ & $\mathbf{x}$ & & & & $\mathbf{x}$ \\
\hline Molguloides cyclocarpa & & & $\mathbf{x}$ & & & $\mathbf{x}$ & & \\
\hline Molgula pyriformis & & $\mathbf{x}$ & & & & $\mathbf{x}$ & & \\
\hline Fungulus perlucidus & & & & $\mathbf{x}$ & & $\mathbf{x}$ & & \\
\hline Paramolgula gregaria* & $\mathbf{x}$ & & & & & $\mathbf{x}$ & & \\
\hline Asajirus indicus & & & $\mathbf{x}$ & $\mathbf{x}$ & & & & $\mathbf{x}$ \\
\hline
\end{tabular}


Family DIDEMNIDAE Giard, 1872

Genus Didemnum Savigny, 1816

Didemnum studeri Hartmeyer, 1911

Didemnum studeri Hartmeyer, 1911: 538.

Geographic distribution: Antarctic and SubAntarctic waters including Tasmania, SE Pacific up to $27^{\circ} \mathrm{S}$ and Patagonian Shelf, South Georgia Island (Van Name 1945; Kott 1969; 1971; Millar 1970; Monniot C. \& Monniot F. 1983 and references therein; Varela 2007; Sanamyan et al. 2010).

References and bathymetric distribution in Uruguayan waters: Barranguet (1988): not detailed, between $37-110 \mathrm{~m}$. Record not yet substantiated (mentioned in abstract).

Didemnum tenue (Herdman, 1886)

Leptoclinum tenue Herdman, 1886: 281, pl. 39, figs. 8-11 and pl. 40, figs. 3-5.

For synonymy see Van Name (1945: 82-83, 86, 90-81) and Marks (1996: 368).

Geographic distribution: SE Pacific, Magellanic Province, Patagonian Shelf up to off Río de La Plata; South Georgia Island (Herdman 1886; Kott 1969; Monniot C. \& Monniot F. 1983 and references therein).

References and bathymetric distribution in Uruguayan waters: Herdman (1886: 281-282): 1097 m (HMS Challenger, st. 320).

Observations: Hartmeyer (1907-1911) included this species in the genus Didemnum.

Genus Coelocormus Herdman, 1886

Coelocormus huxleyi Herdman, 1886

Coelocormus huxleyi Herdman, 1886: 318, pl. 37, figs. 1-8 and pl. 38, figs. 1-4.

Geographicdistribution:onlyknown from thetype locality: Argentine Basin (Uruguay-Argentina).

References and bathymetric distribution in Uruguayan waters: Herdman (1886: 318-319): 1097 m (HMS Challenger, st. 320).

\section{Family DIAZONIDAE Garstang, 1891}

Genus Pseudodiazona Millar, 1963

Pseudodiazona abyssa Monniot C. \& Monniot F., 1974

Pseudodiazona abyssa Monniot C. \& Monniot F., 1974: 733, fig. 4.

Geographic distribution: N Atlantic; Mediterranean Sea; SE Atlantic; W Indian Ocean?; Guyana-Suriname Basin; Argentine Basin (Monniot C. \& Monniot F. 1974; 1976a; 1976b; 1977b; 1984; 1985a; 1985b; 1987; 1988; Monniot F. \& Monniot C. 1976).

References and bathymetric distribution in Uruguayan waters: Monniot C. \& Monniot F. (1985a: 18): 993-1011 m (collected at RV Atlantis II, cruise 60 , st. 237 ).

Order PHLEBOBRANCHIA Lahille, 1886

Family CIONIDAE Lahille, 1887

Genus Araneum Monniot C. \& Monniot F., 1973

Araneum sigma Monniot C. \& Monniot F., 1973

Araneum sigma Monniot C. \& Monniot F., 1973: 398, figs. 4-5, 18B.

Geographic distribution: N Atlantic; Argentine Basin (Monniot C. \& Monniot F. 1973; 1976a; 1977b; 1979; 1984; 1985a; Monniot F. \& Monniot C. 1976).

References and bathymetric distribution in Uruguayan waters: Monniot F. \& Monniot C. (1976: 630; 632): 2440-2480 m (RV Atlantis II, cruise 60 , st. 262).

Family AGNEZIIDAE Monniot C. \& Monniot F., 1991

Genus Agnezia Monniot C. \& Monniot F., 1991

Observations: Agnesia Michaelsen, 1898 is a preoccupied name; therefore, Agnesiidae Huntsman 1912 is not valid. Monniot C. \& Monniot F. (1991) suggested the new names Agnezia and Agneziidae as replacement names. 
Agnezia celtica (Monniot C. \& Monniot F., Monniot F., 1976 1974)

Agnesia celtica Monniot C. \& Monniot F., 1974: Caenagnesia complementa Monniot F. \& Monniot C., 1976: 636, fig. 4. 743, fig. 8 .

Geographic distribution: N Atlantic; SE Atlantic; W Indian Ocean; Brazil Basin; Argentine Basin (Monniot F. \& Monniot C. 1976; Monniot C. \& Monniot F. 1974; 1977b; 1984; 1985a; 1985b; 1985c; Monniot C. 1994).

References and bathymetric distribution in Uruguayan waters: Monniot F. \& Monniot C. (1976: 630; 633): 3906-3917 m (RV Atlantis II, cruise 60 , st. 256).

Genus Adagnesia Kott, 1963

Geographic distribution: only known from the type locality: Argentine Basin (Uruguay).

References and bathymetric distribution in Uruguayan waters: Monniot F. \& Monniot C. (1976: 630; 639): 1661-1679 m (RV Atlantis II, cruise 60 , st. 239).

\section{Family ASCIDIIDAE Herdman, 1882}

Genus Ascidia Linnaeus, 1767

Ascidia meridionalis Herdman, 1880

Adagnesia charcoti Monniot C. \& Monniot F., 1973

Adagnesia charcoti Monniot C. \& Monniot F., 1973: 424, figs. 16-17, 18D.

Geographic distribution: N Atlantic; Indian Ocean; Southern Ocean (South Shetland Islands and Macquarie Island); Guyana-Suriname Basin; Argentine Basin (Millar 1978; 1982a; Monniot C. \& Monniot F, 1973; 1974; 1976a; 1977b; 1984; 1985a; 1985c; Monniot F. \& Monniot C. 1976; Monniot C. 1994; Sanamyan K.E. \& Sanamyan N.P. $1999 ;$ 2002).

References and bathymetric distribution in Uruguayan waters: Monniot F. \& Monniot C. (1976: 630 -as Adagnesia sp.-; 634; 1985a: 8, 23): 1661$2323 \mathrm{~m}$, collected at RV Atlantis II, cruise 60, sts. 239 and 240.

Observations: As already noted by Sanamyan K.E. \& Sanamyan N.P. (2002), the material collected in the Argentine Basin mentioned by Monniot F. \& Monniot C. (1976, Table 1) as Adagnesia sp. also belongs to $A$. charcoti as stated by the authors in the same work (1976). The shallow water $(22 \mathrm{~m})$ record of this species for the Southwest Pacific (Bass Strait) (Kott 1985; 2005) has been questioned by Sanamyan K.E. \& Sanamyan N.P. (1999).

Genus Caenagnesia Ärnbäck-Christie-Linde, 1938

Caenagnesia complementa Monniot C. \&

Ascidia meridionalis Herdman, 1880: 465, Herdman 1882: 207, pl. 31, figs. 4-8.

Ascidia tenera Herdman 1880: 467, Herdman 1882: 213, pl. 32, figs. 7-10.

For synonymy see Monniot C. \& Monniot F. (1983: 60-66).

Geographic distribution: Antarctic and SubAntarctic areas, up to off Río de La Plata in the SW Atlantic (Van Name 1945; Kott 1969; 1971; Monniot C. 1970; Monniot C. \& Monniot F. 1983; Tatián et al. 2005; Monniot et al. 2011).

References and bathymetric distribution in Uruguayan waters: Herdman (1880: 465, 467-468; 1882: 207-209): $1097 \mathrm{~m}$.

Observations: collected at HMS Challenger st. 320 , which is the type locality of this species and its synonym Ascidia tenera (Herdman 1880; 1882; Kott 1969; Monniot F. \& Monniot C. 1976; Monniot C. \& Monniot F. 1983).

Family CORELLIDAE Lahille, 1887

Genus Corella Alder and Hancock, 1870 (in Hancock, 1870)

\section{Corella sp.}

References and bathymetric distribution in Uruguayan waters: Obenat et al. (2001): 11-12 m, outer Río de La Plata estuary.

Observations: specimens found within clumps of the polychaete Phyllochaetopterus socialis 
(Claparède 2001) were listed in a benthic study without description allowing verification of the record. Corella eumyota Traustedt, 1882 was originally described from Valparaiso, Chile, and it is considered as native to the Southern Hemisphere. The species was observed in France for the first time in 2002, probably introduced by anthropogenic transport (Lambert 2004), and thus considered as highly invasive. Using specimens collected at five locations of Chile, Argentina and the South Shetland Islands, Alurralde et al. (2013) distinguished two different species, a concept also supported by Monniot F. (2013). The variability observed defined discrete clusters that were also separated geographically, corresponding to two species of the same genus: Corella eumyota from South America and Corella antarctica Sluiter, 1905 from Antarctica. The latter was even considered until recently as a junior synonym of the former.

Family HYPOBYTHIIDAE Sluiter, 1895

Genus Hypobythius Moseley, 1879

Hypobythius moseleyi Herdman, 1882

Hypobythius moseleyi Herdman, 1882: 231, pl. 37, figs. 6-9.

Geographic distribution: only known from the type locality: Argentine Basin (Uruguay-Argentina).

References and bathymetric distribution in Uruguayan waters: Herdman (1882: 231-232): 1097 m (HMS Challenger, st. 320).

Observations: According to Monniot F. \& Monniot C. (1976) this is a very poorly described species that probably belongs to Dicopia Sluiter, 1905 or Situla Vinogradova, 1969 (Octacnemidae). We support Bonnet (2016) in considering H. moseleyi as beloging to Hypobythius (type species $H$. calycodes Moseley, 1877) included in a different family (Hypobythiidae), although a redescription of that species based on topotypes is clearly needed.

Family OCTACNEMIDAE Herdman, 1888

Genus Octacnemus Moseley, 1877

Octacnemus ingolfi Madsen, 1947
Octacnemus ingolfi Madsen, 1947: 31, 2 a-e, pl. 1.

For synonymy see Sanamyan K.E. \& Sanamyan N.P. (2002: 324).

Geographic distribution: N Atlantic; Indian Ocean; SW Pacific; Guyana-Suriname Basin; Argentine Basin (Madsen 1947; Monniot C. \& Monniot F. 1973; 1977b; 1984; 1985a; 1985b; 1985c; 1991; Monniot F. \& Monniot C. 1976).

References and bathymetric distribution in Uruguayan waters: Monniot F. \& Monniot C. (1976: 630, 633): 2041-2048 m (RV Atlantis II, cruise 60, st. 264).

Order STOLIDOBRANCHIA Lahille, 1886

Family STYELIDAE Sluiter, 1895

Genus Styela Fleming, 1822

Styela chaini Monniot C. \& Monniot F., 1970

Styela chaini Monniot C. \& Monniot F. 1970: 321, fig. 4.

Geographic distribution: N Atlantic; Argentine Basin (Monniot C. \& Monniot F. 1970; 1973; 1974; 1977b; 1984; 1985a; Monniot F. \& Monniot C. 1976; Millar 1982a).

References and bathymetric distribution in Uruguayan waters: Monniot F. \& Monniot C. (1976) and Monniot C. \& Monniot F. (1985a): 1661-2707 m (RV Atlantis II, cruise 60, sts. 239, 240, 245, 262 and 264).

\section{Styela flava Herdman, 1881 nomen dubium}

Styela flava Herdman, 1881a: 64; 1882: 160, pl. 20, figs. 1-6.

Geographic distribution: only known from the type locality: Argentine Basin (Uruguay-Argentina).

References and bathymetric distribution in Uruguayan waters: Herdman (1881a; 1882: 160-161): 1097 m (HMS Challenger, sta. 320).

Observations: Shenkar et al. (2018c) considered $S$. flava as a synonym of $S$. squamosa based not only on the concept that the latter is a senior subjective synonym of $S$. oblonga (see discussion 
below under S. squamosa) but also Van Name (1945) suggested a possible synonymy between $S$. flava and S. oblonga (Sanamyan K. pers. comm.). However, due to the lack of information about the gonads, Van Name (1945) considered S. flava as an "insufficiently described form".

Rodrigues (1966), admitting he analyzed only one specimen, established:

"There are many similarities between $S$. flava and my specimens of $S$. glans. The most characteristic are: the arrangement of the tentacles, the dorsal tubercle, the undulated dorsal lamina and the uncommon endostyle. Considering these similarities and absence of information about the gonads of $S$. flava, we conclude that it would be possible to consider this species identical as well as to oblonga as to glans. Therefore S. flava remains as a dubious species and therefore we consider it as a nomen dubium".

Synonymy of S. flava with Styela nordenskjoldi Michaelsen, 1898 (see above comments under $S$. squamosa) proposed by Kott $(1969 ; 1971)$ was rejected by Monniot F. \& Monniot C. (1976), who maintained this species as a different one.

\section{Styela glans Herdman, 1881}

Styela glans Herdman, 1881a: 65; Herdman 1882: 162-163, pl. 20, figs. 10-13; Hartmeyer 1927: 183.

Geographic distribution: Antarctic and SubAntarctic regions including Kerguelen Islands (?), Ross Sea, Weddell Sea, Antarctic Peninsula; Argentine Basin off Río de La Plata (Herdman 1881a; 1882; Monniot C. 1978; Monniot C. \& Monniot F. 1980; 1983; 1994).

References and bathymetric distribution in Uruguayan waters: Herdman (1881a: 65-66; 1882: 162-163): 1097 m (HMS Challenger, st. 320), Monniot F. \& Monniot C. (1976: 630, 643): 1661$1679 \mathrm{~m}$ (RV Atlantis II, cruise 60, st. 239).

Observations: The record of $S$. glans of Rodrigues (1966) from the Brazilian coast (São Paulo's coast, ca. $24^{\circ} \mathrm{S}, 140 \mathrm{~m}$ ) has been questioned by Monniot F. \& Monniot C. (1976) on the basis of differences in the oviducts, tentacles and peripharyngeal band ("sillon pericoronal"). According to Monniot F. \& Monniot C. (1976), S. glans has been confused with several others by Kott
(1969), using the name Styela nordenskjoldi, and thus they rejected the synonymy proposed by that latter author for all the three species of Styela described by Herdman from off Río de La Plata.

Styela plicata (Lesuer, 1823)

Ascidia plicata Lesuer, 1823: 5.

For synonyms see Van Name (1945: 295).

Geographic distribution: worldwide in temperate zones (Barros et al. 2009).

References and bathymetric distribution in Uruguayan waters: Montevideo (Traustedt 1882): failed introduction; Port of La Paloma, Rocha: established population, shallower subtidal (Orensanz et al. 2002; Demicheli \& Scarabino 2006; Tatián, Schwindt \& Scarabino pers. obs.).

Observations: the record of Traustedt (1882), which forms the basis of the record of the species of Van Name (1945) for Uruguay, is most probably based on a failed introduction, likely the hull of a ship. Although S. plicata has some resistance to estuarine conditions (Barros et al. 2009), Montevideo harbor lies within an estuarine zone unsuitable for ascidians without any further record of this or any other ascidian species. This species should be carefully observed/monitored, since it was dispersed worldwide by vessels, as it holds many of the different features to become invasive (Barros et al. 2009; Pineda et al. 2013).

\section{Styela squamosa Herdman, 1881}

Styela squamosa Herdman, 1881a: 66-67.

Styela oblonga Herdman 1881a: 65; 1882: 159, pl. 20, figs. 7-9, Hartmeyer 1927: 183.

For synonymy see Monniot C. \& Monniot F. (1982), Monniot C. (1993: 356-358) and Sanamyan K.E. \& Sanamyan N.P. (2006: 321-325).

Geographic distribution: Antarctic and SubAntarctic areas (Ross Sea, South Georgia and South Orkeys Islands); W Pacific (Sea of Japan; Sea of Okhotsk, Arafura Sea); N Pacific (Aleutian Islands); E Pacific; SE Atlantic; Argentine Basin off Río de La Plata (Herdman 1881a; Millar 1964; 1982b; 1988; Monniot C. \& Monniot F. 1982; 1983; Monniot C. 1993; Sanamyan K.E. \& Sanamyan N.P. 2006; 2012).

References and bathymetric distribution in Uru- 
guayan waters: Herdman (1881a; 1882: 159-160, as $S$. oblonga): $1097 \mathrm{~m}$.

Observations: collected at HMS Challenger st. 320 , which is the type locality of S. oblonga (Herdman 1881a; 1882: 159-160). The synonymy of $S$. oblonga with "Styela nordenskjoeldi" (sensu Kott 1969 and 1971, which includes several species according to Monniot F. \& Monniot C. 1976; Monniot C. \& Monniot F. 1982; 1983) was rejected by Monniot F. \& Monniot C. (1976). These authors $(1982 ; 1983)$ established that most probably (but still with some doubts), $S$. oblonga is a synonym of $S$. squamosa, choosing the latter although $S$. oblonga has page precedence. C. Monniot (1993) and Sanamyan K.E. \& Sanamyan N.P. (2006) confirmed the synonymy between these two species.

\section{Genus Dicarpa Millar, 1955}

Dicarpa spinifera Monniot C. \& Monniot F., 1976

Dicarpa spinifera Monniot F. \& Monniot C., 1976: 641, fig. 7.

Geographic distribution: only known from the abyssal plain of the Argentine Basin (Uruguay).

References and bathymetric distribution in Uruguayan waters: Monniot F. \& Monniot C. (1976: 630, 641); Monniot C. \& Monniot F. (1985a: 8, 26): 3305-3343 m (RV Atlantis II, cruise 60, st. 246 and 259 , the latter being the type locality).

\section{Genus Polycarpa Heller, 1877}

\section{Polycarpa aspera Herdman, 1886}

Polycarpa aspera Herdman, 1886: 415, pl. 47, figs. 3-5.

Geographic distribution: only known from the type locality: Argentine Basin (Uruguay-Argentina).

References and bathymetric distribution in Uruguayan waters: Herdman (1886: 415): $1097 \mathrm{~m}$ (HMS Challenger, st. 320).

Polycarpa pseudoalbatrossi Monniot C. \& Monniot F., 1968

Polycarpa pseudoalbatrossi Monniot C. \& Monniot F., 1968: 14, figs. 3A, 6-7.
Geographic distribution: N Atlantic; SE Atlantic; Argentine Basin (Millar 1982a; Monniot C. \& Monniot F. 1968; 1973; 1974; 1976b; 1977b; 1984; 1985a; Monniot F. \& Monniot C. 1976).

References and bathymetric distribution in Uruguayan waters: Monniot F. \& Monniot C. (1976: 630, 641), Monniot C. \& Monniot F. (1985a: 8, 26-27): 2707-3343 m (RV Atlantis II, cruise 60, sts. 245,246 and 259 ).

Genus Bathystyeloides Seeliger, 1906

Bathystyeloides enderbyanus (Michaelsen, 1904)

Bathyoncus enderbyanus Michaelsen, 1904: 226.

For synonyms see Monniot C. \& Monniot F. (1974: 756) and Sanamyan K.E. \& Sanamyan N.P. (2006: 310).

Geographic distribution: N Atlantic; SE Atlantic; Indian Ocean; Southern Ocean; GuyanaSuriname Basin; Brazil Basin; Argentine Basin (Kott 1969; 1971; Millar 1955; 1970; Monniot C. \& Monniot F. 1973; 1974; 1976a; 1976b; 1977a; 1977b; 1984; 1985a; 1994; Sanamyan K.E. \& Sanamyan N.P. 2002; 2006).

References and bathymetric distribution in Uruguayan waters: Monniot C. \& Monniot F. (1985a: 8, 29-30): 2195-2323 m (RV Atlantis II, cruise 60, st. 240).

\section{Genus Cnemidocarpa Huntsman, 1912}

Cnemidocarpa bathyphila Millar, 1955

Cnemidocarpa bathyphila Millar, 1955: 228, fig. 4.

For synonymy see Monniot et al. (1976: 1190) and Sanamyan K.E. \& Sanamyan N.P. (2002: 339).

Geographic distribution: N Atlantic; NW Indian; SW Pacific; Southern Ocean; Argentine Basin (Monniot C. \& Monniot F. 1970; 1973; 1984; 1985a; Millar 1955; 1959; Kott 1971; Monniot et al. 1976; Sanamyan K.E. \& Sanamyan N.P. 2002).

References and bathymetric distribution in Uruguayan waters: Monniot C. \& Monniot F. (1985a: 8, 28): 2195-2323 m (RV Atlantis II, cruise 60, st. 240). 
Genus Botryllus Gaertner, 1774

Botryllus schlosseri (Pallas, 1766)

For synonymy see Van Name (1945: 220).

Geographic distribution: N Atlantic, North Sea, Mediterranean Sea, SE Pacific, SW Atlantic (Argentina) (e.g. Ruiz et al. 2000; Orensanz et al. 2002; Hewitt et al. 2004; López-Legentil et al. 2006; Ben-Shlomo et al. 2010; Mead et al. 2011; Turon et al. 2016).

References and bathymetric distribution in Uruguayan waters: Scarabino et al. (2014): Port of La Paloma, Rocha, shallower subtidal (Tatián, Schwindt \& Scarabino pers. obs.).

Observations: Rocha et al. (2012) listed a total of five Botryllus species for the Atlantic Ocean, being $B$. schlosseri until now absent in Brazil but present in Argentina (Amor 1964; Orensanz et al. 2002; Schwindt et al. 2014). Botryllus schlosseri is a "species complex" consisting of five genetically divergent clades (named from A to E) that should correspond to five distinct cryptic species (Bock et al. 2012; Yund et al. 2015). Clade A is globally widespread, while clade E has been identified only along the European coasts. The remaining clades B-D are geographically restricted to few European localities.

Clade A, the most common and widespread species, experiences recurrent long-distance dispersion (probably human-mediated) and is highly invasive (Bock et al. 2012). Recently, Brunetti et al. (2017) redescribed clade A in detail based on morphological data and associated it with a "DNA barcode".

Populations of B. schlosseri from South America display high gene diversity. A limited number of genotypes probably founded the Pacific Chilean populations, while the Atlantic Argentinean population was repeatedly colonized by new genotypes. The South and North American populations of $B$. scholsseri showed extensive dissimilarities, suggesting two distinct clades. All clades were supported by COI and 18S (Ben-Shlomo et al. 2010).

Family PYURIDAE Hartmeyer, 1908

Genus Culeolus Herdman, 1881

Culeolus anonymus Monniot C. \& Monniot F., 1976
Culeolus anonymus Monniot F. \& Monniot C., 1976: 645, fig. 9 .

For synonymy see Sanamyan K.E. \& Sanamyan N.P. (2002: 344).

Geographic distribution: Southern Ocean (Weddell Sea); SW Pacific (Kermadec Trench and Macquarie Island); Argentine Basin (Millar 1970; Monniot F. \& Monniot C. 1976; Monniot C. \& Monniot F. 1982; 1985a; Sanamyan K.E. \& Sanamyan N.P. 1999; 2002).

References and bathymetric distribution in Uruguayan waters: Monniot F. \& Monniot C. (1976: 630, 645): 4382-5223 m (RV Atlantis II, cruise 60 , sts. 242 , the type locality of this species, and 247).

Observations: Monniot F. \& Monniot C. (1976) accurately stated that Culeolus is one of the most poorly described genus of Ascidiacea due to the lack of recorded specimens and to the almost exclusive consideration of the external aspect, while the anatomy is much more useful. Moreover, the evaluation of incoming material has revealed the existence of intraspecific variability in characters such as the position of the gonads and the structure of the postero-ventral crest (Sanamyan K.E. \& Sanamyan N.P. 2002; postero-ventral arc, according to Kott 1969). In this way, C. anonymus was originally described as two distinct populations (Monniot F. \& Monniot C. 1976) based on its crest: one group with a continuous crest and the other with a crest consisting of separate papillae. Subsequent sampling, however, evidenced the existence of intermediate forms (Monniot C. \& Monniot F. 1982). Monniot F. \& Monniot C. (1976) also used the position of the gonads in relation to each other and to the gut loop, and the shape of the anus, to establish differences with Culeolus suhmi, the other related species cited for the South Atlantic area. Sanamyan K.E. \& Sanamyan N.P. (2002) finally excluded these as valid comparative characters based on the study of new material. They concluded that the only feature stable enough to distinguish $C$. anonymus from C. suhmi is the general shape of the crest. Additional records of this species from adjacent waters have been reported by Monniot C. \& Monniot F. (1985a) (ca. $38^{\circ} 30^{\prime} \mathrm{S} ; 50^{\circ} 10^{\prime} \mathrm{W}$, $4435 \mathrm{~m}$ ) as well as by Sanamyan K.E. \& Sanamyan N.P. (2002) (ca. $38^{\circ} 40^{\prime} \mathrm{S} ; 48^{\circ} 10^{\prime} \mathrm{W}, 5225$ $\mathrm{m})$ who also described Culeolus likae Sanamyan K.E. \& Sanamyan N.P. 2002 from such station. 
Family MOLGULIDAE Lacaze-Duthiers, 1877

Genus Minipera Monniot C. \& Monniot F., 1974

Minipera tacita Monniot C. \& Monniot F., 1985

Minipera sp. Monniot F. \& Monniot C., 1976: 630, 650, fig. 10A.

Minipera tacita Monniot C. \& Monniot F. 1985a: 32 .

Geographic distribution: only known from the Argentine Basin (Uruguay, abyssal plain).

References and bathymetric distribution in Uruguayan waters: Monniot F. \& Monniot C. (1976: 630, 650), Monniot C. \& Monniot F. (1985a: 8, 32): $3305-3343 \mathrm{~m}$.

Observations: Minipera tacita was first recorded as Minipera sp. from RV Atlantis II, cruise 60, st. 259 (Monniot F. \& Monniot C. 1976) and later described as new species and recorded for RV Atlantis II, cruise 60, st. 246 (Monniot C. \& Monniot F. 1985a). Both stations were performed along a small area around ca. $37^{\circ} 15^{`} \mathrm{~S}-52^{\circ} 45^{`} \mathrm{~W}$.

Genus Protomolgula Monniot, 1971

Protomolgula bythia Monniot, 1971

Protomolgula bythia Monniot F., 1971: 467, fig. $6 \mathrm{~A}, \mathrm{~B}$.

Geographic distribution: NE Atlantic; SE Atlantic; Guyana-Surinam Basin; Brazil Basin; Argentine Basin (Monniot F. 1971; Monniot F. \& Monniot C. 1976; Monniot C. \& Monniot F. 1976a; 1977b; 1984; 1985a).

References for the area: Monniot F. \& Monniot C. (1976: 630, 651); Monniot C. \& Monniot F. (1985a: 8, 33): 2707-3343 m (RV Atlantis II, cruise 60 , sts. 245, 246 and 259).

\section{Genus Molguloides Huntsman, 1922}

Molguloides cyclocarpa Monniot C. \& Monniot F., 1982

Molguloides sp. Monniot F. \& Monniot C., 1976: 652 , figs. $10 \mathrm{D}$ and $10 \mathrm{E}$.

Molguloides cyclocarpa Monniot C. \& Monniot F.
1982: 127, figs. 36 and 37, pl. 5 B.

Geographic distribution: SE Atlantic; Southern Ocean (Scotia Sea); Argentine Basin (Uruguay, lower continental slope) (Monniot F. \& Monniot C. 1976; Monniot C. \& Monniot F. 1982; 1985a; Sanamyan K.E. \& Sanamyan N.P. 2002).

References and bathymetric distribution in Uruguayan waters: Monniot F. \& Monniot C. (1976: 630, 652): 2408-2480 m.

Observations: the first description of this species was based on young specimens obtained at RV Atlantis II, cruise 60, st. 262 and therefore specific identification was not possible at the time (Monniot F. \& Monniot C. 1976). However, the same authors further assigned these and new adult individuals obtained from the Southern Ocean to their new species Molguloides cyclocarpa (see Monniot C. \& Monniot F. 1982). Sanamyan K.E. \& Sanamyan N.P. (2002), noting the similarity of some internal characters of $M$. cyclocarpa with Molguloides translucidus Monniot C. \& Monniot F. 1991, proposed that these may be conspecific, although maintained them as separate species. Their individual status is currently accepted until additional material is revised (Sanamyan K.E. \& Sanamyan N.P. 2002).

Genus Molgula Forbes, 1848

Molgula pyriformis Herdman, 1881

Molgula pyriformis Herdman, 1881b: 236; Herdman 1882: 79: pl. 6, figs. 1-3.

For synonymy see Monniot C. \& Monniot F. (1983: 101).

Geographic distribution: off Río de La Plata to Tierra del Fuego and South Georgia Islands (Monniot F. \& Monniot C. 1976; Monniot C. \& Monniot F. 1983).

References and bathymetric distribution in Uruguayan waters: Herdman (1881b: 236-237; 1882: 79-80): 1097 m (HMS Challenger, st. 320), Monniot F. \& Monniot C. (1976: 630; 652-655): 497$1011 \mathrm{~m}$ (RV Atlantis II, cruise 60, sts. 236 and 237).

Observations: Monniot F. \& Monniot C. (1976: 630 ; 652-655) did not agree with the identification of Kott (1969) who recorded this species from the Drake Passage. They supported the more bio- 
geographically anomalous record of Rodrigues (1966), as M. piriformis (sic) from Brazilian coast (São Paulo's coast, ca. $24^{\circ} \mathrm{S}, 140 \mathrm{~m}$ ). Lately, Monniot C. \& Monniot F. (1983) and Monniot C. \& Andrade (1983) stated that the correspondence of this species with the record of Rodrigues (1966) is uncertain as they noted differences in gonads, stomach and stigmata. Monniot C. \& Monniot F. (1983) included in other species of Molgula several records of $M$. pyriformis performed in the Magellanic area for other authors (Michaelsen 1900; Kott 1969).

Genus Fungulus Herdman, 1882

Fungulus perlucidus (Herdman, 1881)

Culeolus perlucidus Herdman, 1881a: 86; 1882: 111, pl. 11, figs. 10-14; pl. 12, figs. 8-12.

Geographic distribution: Southern Ocean (north of Ross Sea) and Sub-Antarctic Islands (Scotia Sea, South Sandwich Trench, Kerguelen Islands and Macquarie Island); W Indian Ocean; Argentine Basin (Monniot F. \& Monniot C. 1976; Monniot C. \& Monniot F. 1977a; 1985c; Sanamyan K.E. \& Sanamyan N.P. 1999; 2002).

References for the area: Monniot F. \& Monniot C. (1976: 630; 655): 4382-4402 m (RV Atlantis II, cruise 60 , st. 242 ).

Observations: Monniot F. \& Monniot C. (1976) reclassified this species as Fungulus Herdman, 1882 , a concept shared by Sanamyan K.E. \& Sanamyan N.P. (1999). The latter, however, considered Culeolus parvus Millar, 1970 (as F. parvus) as a probably different species and not a synonym of $F$. perlucidus as stated by Monniot F. \& Monniot C. (1976) based on differences in the branchial sac and musculature. Sanamyan K.E. \& Sanamyan N.P. (2002) reported this species in a locality adjacent to the area here referred (ca. $38^{\circ} 40^{\prime} \mathrm{S} ; 48^{\circ} 10^{\prime} \mathrm{W}$ ) at $5225 \mathrm{~m}$.

Genus Paramolgula Traustedt, 1835

\section{Paramolgula gregaria (Lesson, 1830)}

Cynthia gregaria Lesson, 1830: 157, pl. 52, fig. 3.

For synonymy see Van Name (1945: 428) and Kott (1969: 164).

Geographic distribution: Sub-Antarctic Islands
(South Georgia Islands); SE Pacific; Magellan Strait; Tierra del Fuego, Patagonian Shelf (Kott 1969; 1971; Monniot C. 1970; Diehl 1977; Lagger et al. 2009).

References and bathymetric distribution in Uruguayan waters: Barranguet (1988): not detailed, between $37-110 \mathrm{~m}$. Record not yet substantiated (mentioned in abstract).

Observations: the taxonomy of this genus is in particular need of a revision (Turon et al. 2016).

Genus Asajirus Kott, 1989

\section{Asajirus indicus (Oka, 1913)}

Hexacrobylus indicus Oka, 1913: 6.

Hexacrobylus eunuchus Monniot F. \& Monniot C. 1976: 658, figs. $12 \mathrm{E}$ and 14.

For synonymy see Kott (1992) and Sanamyan K.E. \& Sanamyan N.P. (2006: 342).

Geographic distribution: N Atlantic; Argentine Basin; S Indian Ocean; Pacific (Monniot F. \& Monniot C. 1976; Monniot C. \& Monniot F. 1988; 1990; Kott 1989; 1992; 2005; Sanamyan K.E. \& Sanamyan N.P. 2006).

References and bathymetric distribution in Uruguayan waters: Monniot F. \& Monniot C. (1976: 630; 658; Monniot C. \& Monniot F. 1985a; 33): 2195-3317 m (RV Atlantis II, cruise 60, sts. 245, 259,262 and 264).

Observations: the type locality of $H$. eunuchus was not recorded in the original description (Kott 2005). Monniot F. \& Monniot C. (1976) described Hexacrobylus eunuchus as a new species from the Argentine Basin but latter (Monniot C. \& Monniot F. 1985a) synonymized it with Hexacrobylus indicus Oka, 1913, a concept shared with Kott (1989) who also referred the latter to as the type species of her new genus Asajirus. Monniot C. \& Monniot F. (1990) described several new species of this group and resurrected $H$. eunuchus, including it in their new genus Hexadactylus, which is an objective synonym of Asajirus. Kott (1992; 2005) still considered A. eunuchus as a synonym of $A$. indicus. Finally, Sanamyan K.E. \& Sanamyan N.P. (2006) discussed the characters used by Monniot C. \& Monniot F. (1990) to separate several species (including $A$. eunuchus and A. indicus) and recognized, as Kott (1992; 2005) did, only one species within the genus Asajirus. 
A phylogenetic analysis based on $18 \mathrm{~S}$ rDNA sequences showed that the former Sorberacea/ Hexacrobylidae are in fact highly modified carnivorous Molgulidae (Tatián et al. 2011).

\section{DISCUSSION}

Thirty-eight ascidian species have been recorded until know from Uruguayan waters. Only nine were recorded for the continental shelf; the rest were collected from the slope (21), the abyssal plain (5) or even both deep-sea zones (3). These records show the historical relevance of the determinations of Herdman, Monniot F. and Monniot C., who described the ascidians collected from deep-sea stations by the HMS Challenger and the RV Atlantis II in the Argentine Basin.

The present ascidian list reveals the following distribution patterns for the known species: Shallow water species with temperate distribution. Only two species of this group, Styela plicata and Botryllus schlosseri, have been identified as exotic, although many others are still unreported (Tatián \& Scarabino pers. obs.).

Shelf and deep-sea species with Antarctic/SubAntarctic distribution. This well-known pattern represents the northernmost distribution boundary of the species following the northern flow of several water masses belonging to the cold Malvinas Current (see figure 2). This group consists of 11 species (Table 1), some of them occurring deeper than their Sub-Antarctic areas (e.g. Kott 1969; 1971; Monniot C. \& Monniot F. 1983; Carranza et al. 2007; 2008; Scarabino et al. 2016). Monniot C. \& Monniot F. (1978) and Monniot F. (1979) had already noted the affinity of the Argentine Basin deep-sea ascidian fauna (mostly based on the records here listed) with the Southern Ocean. Biogeographic studies (Ramos-Esplá et al. 2005; Tatián et al. 2005; Primo \& Vázquez 2007) support the idea of the Scotia Arc functioning as a bridge between the Magellan region and the Antarctic.

Deep-sea species only known off Río de La Plata. Eleven species belong to this group, including both solitary and colonial forms. However, it mainly contains species living on the upper slope (Table 1). In fact, only two abyssal species (Dicarpa spinifera and Minipera tacita) are at this moment considered as endemic from off Río de La Plata. At least one species may be synonymous with an Antarctic one (Styela flava) and several others described by Herdman are actually poorly described. Similarly, a high percentage of endemic deep-sea protobranch bivalves have already been reported from off Río de La Plata by Allen \& Sanders (1997), although this has to be additionally assessed (Scarabino et al. 2016).

Deep-sea species having wide distributions. Twelve species belong to this group, consisting almost entirely of solitary species. Most of them have been recorded only from the lower slope but some of them extend to the abyssal plain (Table 1). The wide distribution of deep-sea benthic species is a well documented pattern (e.g. McClain \& Hardy 2010 and references therein), although many of these may represent species-complexes (e.g. Brandt et al. 2012; Havermans et al. 2013). Bathystyeloides enderbyanus and Cnemidocarpa bathyphila are two of the most widespread species of deep-sea ascidians (Sanamyan K.E. \& Sanamyan N.P. 2002; 2006). The eventual role of the North Atlantic Deep Water circulation in maintaining the connectivity among at least Atlantic deep-sea populations must be addressed in the future.

Research on the Uruguayan ascidian fauna should be further directed to record coastline and shelf species in order to detect the presence of exotic ones, as well as to redescribe some enigmatic bathyal species first described by Herdman (1882; 1886). Furthermore, it must be stressed the complete lack of molecular analysis for the deep-sea species recorded from the Argentine Basin currently recognized as world-wide distributed.

\section{ACKNOWLEDGEMENTS}

This work was supported by the Centro Universitario Regional del Este (UdelaR, Uruguay), Dirección Nacional de Recursos Acuáticos (Uruguay), Museo Nacional de Historia Natural (Uruguay) and by the Project "Caracterización del margen continental uruguayo" (ANCAP-Facultad de Ciencias, UdelaR, Uruguay); PEDECIBA and ANII-SNI; the Consejo Nacional de Investigaciones Científicas y Técnicas (Argentina) under Grant PIP CONICET № 20130100508; and the Secretaría de Ciencia y Tecnología (SECyT), Universidad Nacional de Córdoba (Argentina) under Grants $30720130100645 \mathrm{CB}$ and MINCYT-MEC $\mathrm{UR} / 11 / 05$.

We grateful to Rosana M. da Rocha for making available important literature as well as for her opinion (provided with G. Lambert) about the status of Psammaplidium flavum. We also thank Biodiversity Library Heritage for the same reason about literature. All our gratitude 
goes to Dr. Riccardo Brunetti, Tito Lotufo and an anonymous reviewer, who provided a meticulous revision of the MS. We also thank Graciela Fabiano and Orlando Santana for their support/ samples concerning introduced species in Port La Paloma (Uruguay) and C. Barranguet for kind correspondence.

This work is respectfully dedicated to the memory of Claude Monniot (1936-2008) and to our great friend and coauthor, Lobo Orensanz (1945-2015). FS is especially grateful to Inés Pereyra for her permanent support and patience.

\section{REFERENCES}

Allen J.A. \& Sanders H.L. 1997 (“1996”). The zoogeography, diversity and origin of the deep-sea protobranch bivalves of the Atlantic: the epilogue. Progress in Oceanography 38: 95-153. http://dx.doi. org/10.1016/S0079-6611(96)00011-0

Alurralde G., Torre L., Schwindt E., Castilla J.C.C. \& Tatián M. 2013. A re-evaluation of morphological characters of the invasive ascidian Corella eumyota reveals two different species at the tip of South America and in the South Shetland Islands, Antarctica. Polar Biology 36: 957-968. http://dx.doi. org/10.1007/s00300-013-1319-3

Amor A. 1964. Ascidias nuevas para la fauna argentina. Physis 24 (67-70): 351.

Barranguet C. 1988. Ascidias colectadas por el buque "Lerez" (1982). In: Bernal P. \& Tarifeño E. (eds). VIII Jornadas de Ciencias del Mar: 79. Pontificia Universidad Católica de Chile, Área de Biología y Tecnología del Mar (BIOTECMAR), Sede Talcahuano, Chile.

Barros R.C., Rocha R.M. \& Pie M.R. 2009. Humanmediated global dispersion of Styela plicata (Tunicata, Ascidiacea). Aquatic Invasions 4 (1): 45 57. http://dx.doi.org/10.3391/ai.2009.4.1.4

Ben-Shlomo R., Reem E., Douek J. \& Rinkevich B. 2010. Population genetics of the invasive ascidian Botryllus schlosseri from South American coasts. Marine Ecology Progress Series 412: 85-92. http:// dx.doi.org/10.3354/meps08688

Bock D.G., MacIsaac H.J. \& Cristescu M.E. 2012. Multilocus genetic analyses differentiate between widespread and spatially restricted cryptic species in a model ascidian. Proceedings of the Royal Society of London B: Biological Sciences 279 (1737): 23772385. http://dx.doi.org/10.1098/rspb.20112610

Bonnet N.Y.K. 2016. Filogenia e Taxonomia de Phlebobranchia (Tunicata: Ascidiacea). Philogeny and Taxonomy of Phlebobranchia (Tunicata: Ascidiacea). PhD thesis, Federal University of Ceará, Brazil.

Bonnet N.Y.K. \& Rocha R.M. (2011) The Ascidiidae (Ascidiacea: Tunicata) of Coastal Brazil. Zoological Studies 50(6): 809-825. http://zoolstud.sinica.edu. tw/Journals/50.6/809.pdf

Brandt A., Błażewicz-Paszkowycz M., Bamber R., Mühlenhardt-Siegel U., Malyutina M., Kaiser S., Broyer C. \& Havermans C. 2012. Are there wide- spread peracarid species in the deep sea (Crustacea: Malacostraca)? Polish Polar Research 33 (2): 139162. http://dx.doi.org/10.2478/v10183-012-0012-5

Brunetti R., Manni L., Mastrototaro F., Gissi C. \& Gasparini F. 2017. Fixation, description and DNA barcode of a neotype for Botryllus schlosseri (Pallas, 1766) (Tunicata, Ascidiacea). Zootaxa 4353(1): 2950.

Cachés M.A. 1980. Nota sobre la biología de los depósitos fangosos circalitorales frente a Punta del Este, Uruguay. Boletim do Instituto Ocenaográfico do San Pablo 29 (2): 73-74.

Carranza A., Scarabino F., Ortega L. \& Sauco S. 2007. Geographic and bathymetric distribution of Americominella duartei (Neogastropoda: Buccinidae), a bathyal species from the Southwestern Atlantic. Pan-American Journal of Aquatic Sciences 2 (3): 255-260.

Carranza A., Scarabino F., Brazeiro A., Ortega L. \& Martínez S. 2008. Assemblages of megabenthic gastropods from Uruguayan and northern Argentinean shelf: Spatial structure and environmental controls. Continental Shelf Research 28: 788-796. http://dx.doi.org/10.1016/j.csr.2007.12.010

Cunningham R.O. 1871. Notes on the natural history of the straits of the Magellan and west coast of Patagonia made during the voyage of H.M.S. "Nassau" in the years 1866-1869. Linnean Society of London, Zoology 27: 465-502. http://dx.doi. org/10.1038/003484a0

Demicheli M. \& Scarabino F. 2006. Invertebrados bentónicos de La Paloma (Rocha, Uruguay). In: Menafra R., Rodríguez-Gallego L., Scarabino F. \& Conde D. (eds). Bases para la conservación y el manejo de la costa uruguaya: 523-534. Vida Silvestre Uruguay (Sociedad Uruguaya para la Conservación de la Naturaleza), Montevideo, Uruguay.

Diehl M. 1977. Ascidien des Argentinischen Schelfes uaus den Grundtrawl-Fängen des FFIG "Walther Herwig" auf seiner dritten Sudamerika-Expedition. Mitteilungen aus dem Hamburgischen Zoologischen Museum und Institute 74: 139-153.

Hanebuth T.J.J., Lantzsch H., Pérez L. \& GarcíaRodríguez F. 2018. Sedimentación controlada por corrientes: registros de depósitos paleo-hidrodinámicos inferidos de la plataforma continental del SE de América del Sur (Uruguay). In: Muniz P., Conde D., Venturini N. \& Brugnoli E. (eds). Ciencias Marino Costeras en el Umbral del Siglo XXI: Desafios en Latinoamérica y el Caribe (XV COLACMAR). In press.

Hartmeyer R. 1907-1911. Ascidien. In: Bronn H.G. (ed). Klassen und Ordnungen des Tier-reichs. Suppl. 3: 81-98 and 1281-1773, Leipzig.

Hartmeyer R. 1911. Die Ascidien der deutschen Südpolar-Expedition 1901-1903. In: von Georg Reimer (ed). Deutsche Südpolar Expedition 12 (5): 403-606, Berlin.

Hartmeyer R. 1927. Zur Kenntnis phlebobranchiater und diktyobranchiater Ascidien. Mitteilungen aus dem Zoologischen Museum in Berlin 13: 159-196.

Havermans C., Sonet G., d'Udekem d'Acoz C., Nagy Z.T. \& Martin P. 2013. Genetic and Morphological Divergences in the Cosmopolitan Deep-Sea Amphipod Eurythenes gryllus Reveal a Diverse Abyss and a Bipolar Species. PLoS ONE 8 
(9): e74218. http://dx.doi.org/10.1371/journal. pone. 0074218

Herdman W.A. 1880. Preliminary report on the Tunicata of the Challenger expedition. I. Ascidiadae. Proceedings of the Royal Society of Edinburgh 10 (1): 458-472.

Herdman W.A. 1881a. Preliminary report on the Tunicata of the Challenger expedition. Part III. Cynthiadae. Proceedings of the Royal Society of Edinburgh 11 (3): 52-88.

Herdman W.A. 1881b. Preliminary report on the Tunicata of the Challenger expedition. Part IV. Molgulidae. Proceedings of the Royal Society of Edinburgh 11 (3): 233-240.

Herdman W.A. 1882. Report on the Tunicata collected by H.M.S. Challenger during the years 1873-76. Report of the Scientific Results of the Voyage of the H. M. S. Challenger during the years $1873-76 \ldots$, Zoology 6 (17): 1-296.

Herdman W.A. 1886. Report on the Tunicata collected by H. M. S. Challenger during the years 187376. Part II, Ascidiae compositae. Report of the Scientific Results of the Voyage of the H. M. S. Challenger during the years 1873-76..., Zoology 14 (38): 1-425.

Hewitt C.L., Campbell M.L., Thresher R.E., Martin R.B., Boyd S., Cohen B.F., Currie M.F., Gomon M.J., Keogh J.A., Lewis M.M., Lockett N.M., McArthur M.A., O'Hara T.D., Poore G.C.B., Ross D.J., Storey M.J., Watson J.E. \& Wilson R.S. 2004. Introduced and cryptogenic species in Port Phillip Bay, Victoria, Australia. Marine Biology 144: 183. http://dx.doi.org/10.1007/s00227-003-1173-x

Juanicó M. \& Rodríguez-Moyano M. 1976 (“1975”). Composición faunística de la comunidad de Mytilus edulis platensis d'Orbigny, 1846, ubicada a unas 55 millas al SE de La Paloma. Comunicaciones de la Sociedad Malacológica del Uruguay 4 (29):113116.

Kott P. 1969. Antarctic Ascidiacea. Antarctic Research Series 13: 1-239.

Kott P. 1971. Antarctic Ascidiacea II. Antarctic Research Series 17: 11-81.

Kott P. 1985. The Australian Ascidiacea part I, Phlebobranchia and Stolidobranchia. Memoirs of the Queensland Museum 23: 1-440.

Kott P. 1989. The family Hexacrobylidae Seeliger, 1906 (Ascidiacea, Tunicata). Memoirs of the Queensland Museum 27: 517-534.

Kott P. 1992. The Australian Ascidiacea, supplement 2. Memoirs of the Queensland Museum 32 (2): 621655.

Kott P. 2005. Catalogue of Tunicata in Australian waters. Australian Biological Resources Study, Department of the Environment and Heritage, Australia.

Kott P. 2006. Observations on non-didemnid ascidians from Australian waters (1). Journal of Natural History 40 (3-4): 169-234. http://dx.doi. org $/ 10.1080 / 00222930600621601$

Lagger C. \& Tatián M. 2013. Two new species of Distaplia (Tunicata: Ascidiacea) from the SW Atlantic, Argentina. Zootaxa 3620 (2): 192-200. http://dx.doi.org/10.11646/zootaxa.3620.1.10

Lagger C., Häussermann V., Fösterra G. \& Tatián M. 2009. Ascidians from the southern Chilean Comau
Fjord (Chordata, Ascidiacea). Spixiana 32 (2): 173185.

Lambert G. 2004. The south temperate and Antarctic ascidian Corella eumyota reported in two harbours in north-western France. Journal of the Marine Biological Association of the UK 84: 239-241. http:// dx.doi.org/10.1017/s0025315404009105h

Lesson R.P. 1830. Zoologie. In: Duperrey L.I. (ed). Voyage autour du monde sur "La Coquille" pendant 1882-1825, Tome 2, 1ere Partie, Paris.

Lesuer C.A. 1823. Descriptions of several new species of Ascidians. Journal of the Academy of National Science of Philadelphia 3: 2-8.

López-Legentil S., Turon X. \& Planes S. 2006. Genetic structure of the star sea squirt, Botryllus schlosseri, introduced in southern European harbours. Molecular Ecology 15 (13): 3957-3967. http:// dx.doi.org/10.1111/j.1365-294X.2006.03087.x

Madsen F.J. 1947. Octacnemus ingolfi n. sp., an Atlantic representative of the peculiar tunicatefamily Octacnemidae. Videnskabelige Meddelelser fra Dansk naturhistorisk Forening 110: 31-44.

Maggioni T., Taverna A \& Tatián M. 2016. Redescription of the colonial ascidian Synoicum molle (Herdman, 1886): first record since its original finding during the Challenger Expedition. Zoosystematics and Evolution 92 (2): 181-185. http://dx.doi.org/10.3897/ zse.92.9521

Marks J.A. 1996. Three sibling species of didemnid ascidians from northern Norway: Didemnum albidum (Verrill, 1871), Didemnum polare (Hartmeyer, 1903), and Didemnum romssae sp. nov. Canadian Journal of Zoology 74 (2): 357-379. http://dx.doi. org/10.1139/z96.043

McClain C.R. \& Hardy S.M. 2010. The dynamics of biogeographic ranges in the deep sea. Proceedings of the Royal Society B 277: 3533-3546. http://dx.doi. org/10.1098/rspb.2010.1057

Mead M., Carlton J.T., Griffiths C.L. \& Rius M. 2011. Revealing the scale of marine bioinvasions in developing regions: a South African re-assessment. Biological Invasions 13: 1991-2008. http://dx.doi. org/10.1007/s10530-011-0016-9

Michaelsen W. 1900. Die holosomen Ascidien des magalhaensischsüdgeorgischen Gebietes. Zoologica 12: 1-146.

Michaelsen W. 1904.DieStolidobranchiaten Ascidien der deutschen TiefseeExpedition. Wissenschaftlichen Ergebnisse der Deutschen Tiefsee-Expedition audem Dampfer "Valdivia" 1898-1899 7 (2): 181260.

Michaelsen W. 1907. Tunicaten. In: Friederischen L. (ed). Ergebneisse der Hamburger magalhaensischen Sammelreise 1892-93: 1-84. Hamburgisches Zoologisches Museum und Institut, Hamburg. http://dx.doi.org/10.5962/bhl.title.63772

Michaelsen W. 1924. Ascidien Krikobranchie von Neuseeland, den Chatham und den AucklandInseln.Viednskabelige Meddelelser fra Dansk Naturhistorisk Forening 77: 263-434.

Millar R.H. 1955. Ascidiacea. Reports of the Swedish Deep-Sea Expedition 2 (18): 221-236.

Millar R.H. 1959. Ascidiacea. Galathea Report 1: 189209.

Millar R.H. 1960. Ascidiacea. Discovery Reports, National Institute of Oceanography, Cambridge. 
Millar R H. 1964. Ascidiacea: The additional material. Galathea Report 7: 59-62.

Millar R.H. 1969. Ascidiacea: Some further specimens. Galathea Report 10: 91-98.

Millar R.H. 1970. Ascidians, including specimens from the deep sea, collected by the RV Vema and now in the American Museum of Natural History. Zoological Journal of the Linnean Society 49: 99159. http://dx.doi.org/10.1111/j.1096-3642.1970. tb00732.x

Millar R.H. 1978. Ascidians from the Guyana shelf. Journal of Sea Research 12 (1): 99-106. http:// dx.doi.org/10.1016/0077-7579(78)90027-3

Millar R.H. 1982a. Ascidians from the Rockall Trough area of the Northeast Atlantic. Journal of Natural History 16: 165-182. http://dx.doi. org $/ 10.1080 / 00222938200770131$

Millar R.H. 1982b. The marine fauna of New Zealand: Ascidiacea. New Zealand Oceanographic Institute Memoir 85: 1-117.

Millar R.H. 1988. Deep-sea ascidians from the eastern Pacific Ocean Biological Survey Program. Journal of Natural History 22: 1427-1435. http://dx.doi. org $/ 10.1080 / 00222938800770851$

Milstein A., Juanicó M. \& Olazarri J. 1976. Algunas asociaciones bentónicas frente a las costas de Rocha, Uruguay. Resultados de la campaña del R/V "Hero", viaje 72-3A. Comunicaciones de la Sociedad Malacológica del Uruguay 4 (50), 143-164.

Monniot C. 1970. Ascidies phlébobranches et stolidobranches. Campagne de la Calypso au large des côtes de l'Amérique du Sud. Annales de l'Institut océanographique 47, 33-59.

Monniot C. 1978. Ascidies Phlébobranches et Stolidobranches du Sud de l'Océan Indien. Annales de l'Institute océanographique 54 (2): 171-224.

Monniot C. 1993. Tunicata: sur trois espèces d'ascidies bathyales récoltées au cours de la campagne francoindonésienne Karubar. In: A. Cosnier (ed). Volume 11: Résultats des Campagnes Musorstom. Mémoirs du Muséum national d'Histoire naturelle 158: 355359.

Monniot C. 1994. Quelques ascidies récolteés par le M. S. 'Marion-Dufresne' (Campagne Jasus, Réunion et Brésil). Vie Milieu 44 (3/4): 229-242.

Monniot C. \& Andrade H. 1983. Ascidias arquibénticas de Chile central. Revista de Biología Marina 19 (2): 133-141.

Monniot C. \& Monniot F. 1968. Les ascidies de grandes profondeurs récoltées par le navire océanographique américain Atlantis II (prémiere note). Bulletin de l'Institute océanographique 67 (1379): 48 pp.

Monniot C. \& Monniot F. 1970. Les ascidies de grandes profondeurs récoltées par les navires Atlantis II et Chain (2ème note). Deep-Sea Research 17: 317-336

Monniot C. \& Monniot F. 1973. Ascidies abyssales récoltées au cours de la campagne océanographique Biaçores par le «Jean-Charcot». Bulletin du Muséum national d'Histoire naturelle, $3^{\circ}$ série, Zoologie $93 \mathrm{n}^{\circ}$ 121: 389-475.

Monniot C. \& Monniot F. 1974. Ascidies abyssales de l'Atlantique récoltées par le «Jean-Charcot» (Campagnes Noratlante, Walda, Polygas A). Bulletin du Muséum national d'Histoire naturelle, $3^{\circ}$ série, Zoologie 154, $\mathrm{n}^{\circ}$ 226: 721-786.

Monniot C. \& Monniot F. 1976a. Some species of abys- sal ascidians from the Surinam basin. Bulletin $d u$ Museum national d'Histoire naturelle, $3^{\circ}$ série, Zoologie 269, n 387: 663-670.

Monniot C. \& Monniot F. 1976b. Quelques ascidies bathyales et abyssales du Sud Est Atlantique. Bulletin du Museum national d'Histoire naturelle, $3^{\circ}$ série, Zoologie 269, n 387: 671-680.

Monniot C. \& Monniot F. 1977a. Quelques ascidies abyssales du Sud-Ouest de 1'Océan Indien. CNFRA 42: 305-327.

Monniot C. \& Monniot F. 1977b. Tuniciers benthiques profonds du Nord-Est Atlantique. Resultats des campagnes Biogas. Bulletin du Museum national d'Histoire naturelle, $3^{\circ}$ série, Zoologie $323 \mathrm{n}^{\circ} 466$ : 695-719.

Monniot C. \& Monniot F. 1978. Recent work on the deep-sea Tunicates. Oceanography and Marine Biological: An Annual Review 16: 181-228.

Monniot C. \& Monniot F. 1979. Tuniciers benthiques récoltés au cours de la campagne Norbi en mer de Norvège. Bulletin du Museum national d'Histoire naturelle, $4^{\circ}$ série, 1 , section A (3): 563-573.

Monniot C. \& Monniot F. 1980. Sur quelques Ascidies récoltées sous le pack en baie de McMurdo, Antarctique. Bulletin $d u$ Museum national d'Histoire naturelle, $4^{\circ}$ série, 2 , section A (1): 1525.

Monniot C. \& Monniot F. 1982. Some Antarctic deepsea tunicates in the Smithsonian collections. In: L.S. Kornicker (ed). Biology of the Antarctic Seas X, Antarctic Research Series 32: 95-130. American Geophysical Union, United States.

Monniot C. \& Monniot F. 1983. Ascidies antarctiques et subantartiques: morphologie et biogeography [Antarctic and Sub-Antarctic ascidians: morphology and biogeography]. Mémories du Museum National d'Historie Naturelle, série A, Zoologie 125: 1-168.

Monniot C. \& Monniot F. 1984. Tuniciers benthiques récoltés au cours de la champagne Abyplaine au large de Madére. Annales de l'Institut océanographique 60 (2): 129-142.

Monniot C. \& Monniot F. 1985a. Nouvelles récoltes de Tuniciers benthiques profonds dans l'océan Atlantique. Bulletin du Museum National d'Historie Naturelle, série 4, section A 7 (1): 5-37.

Monniot C. \& Monniot F. 1985b. Ascidies profondes au large de Myote (Archipel des Comores). Cahiers de Biologie Marine 26 (1): 35-52.

Monniot C. \& Monniot F. 1985c. Tuniciers profondes de l'Ocean Indien: campagnes SAFARI du "Marion Dufresne". Bulletin du Museum National d'Historie Naturelle, section A 7 (2): 279-308.

Monniot C. \& Monniot F. 1987. Abundance and distribution of tunicates on the northern continental slope of the Gulf of Mexico. Bulletin of Marine Science 41 (1): 36-44.

Monniot C. \& Monniot F. 1988. Ascidies profondes de chaque cote du seuil de Gibraltar (Campagne BALGIM). Bulletin du Museum national d'Histoire naturelle, section A 10 (3): 415-428.

Monniot C. \& Monniot F. 1990. Revision of the class Sorberacea (benthic tunicates) with descriptions of seven new species. Zoological Journal of the Linnean Society 99: 239-290. http://dx.doi. org/10.1111/j.1096-3642.1990.tb00562.x 
Monniot C. \& Monniot F. 1991. Tunicata: peuplements d'ascidies profondes en Nouvelle-Calédonie. Diversité des stratégies adaptatives. In: A. Cosnier (ed). Volume 8: Résultats des Campagnes MUSORSTOM. Mémoirs du Muséum National d'Histoire Naturelle (A), 151: 357-448.

Monniot C. \& Monniot F. 1994. Ascidians collected in the Weddell Sea by the RV "Polarstern" (EPOS cruise leg 3). Bulletin du Museum national d'Histoire naturelle, $4^{\circ}$ série, 16 , section A (1): 13-37.

Monniot C., Monniot F. \& Millar R.H. (1976) An account of six species of abyssal Styelidae (Ascidiacea), three of which are new species. Deep-Sea Research 23: 1187-1197. http://dx.doi.org/10.1016/00117471(76)90894-9

Monniot F. 1971. Les ascidies de grandes profondeurs recoltees par les navires 'Atlantis 2' et 'Chain'. 3 note. Cahiers de Biologie Marine 12: 457-469.

Monniot F. 1979. Faunal affinities among abyssal Atlantic basins. Sarsia, 64, 93-95. http://dx.doi.or $\mathrm{g} / 10.1080 / 00364827.1979 .10411368$

Monniot F. 2013. The genus Corella (Ascidiacea, Phlebobranchia, Corellidae) in the Southern Hemisphere with description of a new species. Zootaxa 3702 (2): 135-149. http://dx.doi. org/10.11646/zootaxa.3702.2.3

Monniot F. \& Monniot C. 1976. Tuniciers abyssaux du bassin argentin récoltés par l' «Atlantis II". Bulletin du Museum national d'Histoire naturelle, Zoologie, $3^{\circ}$ série, Zoologie 269, n 387, 629-662.

Monniot F., Dettai A., Eleaume M., Craud C. \& Ameziane N. 2011. Antarctic Ascidians (Tunicata) of the French-Australian survey CEAMARC in Terre Adélie. Zootaxa 2817: 1-54.

Moreno T.R., Faria S.B. \& Rocha R.M. 2014. Biogeography of Atlantic and Mediterranean ascidians. Marine Biology 161: 2023. http://dx.doi. org/10.1007/s00227-014-2483-x

Obenat S., Ferrero L. \& Spivak E. 2001. Macrofauna associated with Phyllochaetopterus socialis aggregations in the southwestern Atlantic. Vie et Milieu 51 (51): 131-139.

Oka A. 1913. Zur kenntnis der zwei aberranten Ascidien Gattungen Dicopia Sluit und Hexacrobylus Sluit. Zoologischer Anzeiger 43: 1-10.

Orensanz J.M. (Lobo), Schwindt E., Pastorino G., Bortolus A., Casas G., Darrigrán G., Elías R., LópezGappa J.J., Obenat S., Pascual M., Penchaszadeh P., Piriz M.L., Scarabino F., Spivak E.D. \& Villarino E.A. 2002. No longer the pristine confines of the world ocean: a survey of exotic marine species in the southwestern Atlantic. Biological Invasions 4: 115143. http://dx.doi.org/10.1023/A:1020596916153

Pineda M., Turon X., Pérez-Portela R. \& LópezLegentil S. 2013. Life after the death: renewal of introduced Styela plicata populations after die-off episodes of North Carolina, USAE. In: Branno M., Ristoratore F., Spagnuolo A. \& Russo G.F. (eds). 7th International Tunicate Meeting: 87-88. Universitá degli Studi Di Napoli "Parthenope", Naples, Italy. http://dx.doi.org/10.13140/2.1.2496.3841

Primo C. \& Vázquez E. 2007. Zoogeography of the Antarctic ascidian fauna in relaiton to the subAntarctic and South America. Antarctic Science 19 (3): 321-336.

Ramos-Esplá A.A., Cárcel J.A. \& Varela M. 2005.
Zoogeographical relationships of the littoral ascidiofauna around the Antarctic Peninsula, in the Scotia Arc and in the Magellan region. Scientia Marina 69(2): 215-223.

Rocha R.M. \& Costa L.V.G. 2005. Ascidians (Urochordata: Ascidiacea) from Arraial do Cabo, Rio de Janeiro, Brazil. Iheringia, Série Zoología 95 (1): 57-64. http://dx.doi.org/10.1590/S007347212005000100009

Rocha R.M., Bastos Zanata T. \& Moreno T.R. 2012. Key for the identification of families and genera of Atlantic shallow water ascidians. Biota Neotropica 12 (1): 269-303. http://dx.doi.org/10.1590/s167606032012000100022

Rocha R.M., Neves I.M. \& Gamba G.A. 2015. New species of Didemnidae (Tunicata: Ascidiacea) from the tropical coast of Brazil. Zootaxa, 3905 (3): 381-396. http://dx.doi.org/10.11646/zootaxa.3905.3.4

Rodrigues S.A. 1966. Notes on Brazilian ascidians 1. Papéis Avulsos do Departamento de Zoologia 19 (8): 95-115.

Ruiz G.M., Fofonoff P., Carlton J.T., Wonham M.J. \& Hines A.J. 2000. Invasion of coastal marine communities in North America: apparent patterns, processes and biases. Annual Review of Ecology Systematics 31: 481-531. http://dx.doi.org/10.1146/ annurev.ecolsys.31.1.481

Sagular E.K. 2009. Fossil didemnind ascidian spicule records in the Plio-Quaternary marine clastics of the Antalya basin (Eastern Mediterranean) and their stratigraphic calibration to new nannofossil data. Geosciences Journal 13 (2): 121-131.

Sagular E.K., Yümün Z.Ü. \& Engin M. 2017. New didemnid ascidian spicule records calibrated to the nannofossil data chronostatigraphically in the Quaternary marine deposits of Lake Íznik (NW Turkey) and their paleoenvironmental interpretations. Quaternary International: 1-13. https://doi. org/10.1016/j.quaint.2017.08.060

Sanamyan K.E. \& Sanamyan N.P. 1999. Some benthic Tunicata from the southern Indo Pacific Ocean. Journal of Natural History 33: 1835-1876. http:// dx.doi.org/10.1080/002229399299761

Sanamyan K.E. \& Sanamyan N.P. 2002. Deep-water ascidians from the south-western Atlantic (RV Dmitry Mendeleev, cruise 43 and Academic Kurchatov, cruise 11). Journal of Natural History 36 (3): 305359. http://dx.doi.org/10.1080/00222930010004232

Sanamyan K.E. \& Sanamyan N.P. 2006. Deepwater ascidians (Tunicata: Ascidiacea) from the northern and western Pacific. Journal of Natural History, 40 (5-6), 307-344. http://dx.doi. org/10.1080/00222930600628416

Sanamyan K.E. \& Sanamyan N.P. 2012. Deep-water Ascidiacea from the Sea of Japan. Zootaxa 3245: 63-68.

Sanamyan K.E. \& Schories D. 2003. Ascidians from the Strait of Magellan. Journal of Ichthyology and Aquatic Biology 7 (3): 89-96.

Sanamyan K.E., Schories D. \& Sanamyan N.P. 2010. New records of aplousobranch ascidians from Central Chile. Zootaxa 2537: 58-68. http://dx.doi. org/10.5281/zenodo.196669

Scarabino F. 2006. Faunística y taxonomía de invertebrados bentónicos marinos y estuarinos de la costa uruguaya. In: Menafra R., Rodríguez-Gallego L., 
Scarabino F. \& Conde D. (eds). Bases para la conservación y el manejo de la costa uruguaya: 113-142. Vida Silvestre Uruguay (Sociedad Uruguaya para la Conservación de la Naturaleza), Montevideo, Uruguay.

Scarabino F., Maggioni T., Taverna A., Lagger C., Ortega L., Schwindt E., Orensanz J.M., López G. \& Tatián M. 2014. Ascidiacea de aguas uruguayas: lista de especies y consideraciones biogeográficas. In: Pereira G. \& Maneyro R. (eds). Tercer Congreso Uruguayo de Zoología "Prof. Dr. Raúl Vaz - Ferreira": 127. Facultad de Ciencias, Universidad de la República, Montevideo, Uruguay.

Scarabino F., Zelaya D.G., Orensanz J.M. (Lobo), Ortega L., Defeo O., Schwindt E., Carranza A., Zaffaroni J.C., Martínez G., Scarabino V. \& GarcíaRodríguez F. 2016. Cold, warm, temperate and brackish: Bivalve biodiversity in a complex oceanographic scenario (Uruguay, southwestern Atlantic). American Malacological Bulletin 33 (2): 284-301. http://dx.doi.org/10.4003/006.033.0219

Schwindt E., López Gappa J., Raffo M.P., Tatián M., Bortolus A., Orensanz J.M. (Lobo), Alonso G., Diez M.E., Doti B., Genzano G., Lagger C., Lovrich G., Piriz M.L., Mendez M.M., Savoya V. \& Sueiro M.C. 2014. Marine fouling invasions in ports of Patagonia (Argentina) with implications for legislation and monitoring programs. Marine Environmental Research 99 (2014): 60-68. http:// dx.doi.org/10.1016/j.marenvres.2014.06.006

Shenkar N. \& Swalla B.J. 2011. Global Diversity of Ascidiacea. PLoS ONE 6 (6): e20657. http://dx.doi. org/10.1371/journal.pone.0020657

Shenkar N., Gittenberger A., Lambert G., Ruis M., Moreira Da Rocha R., Swalla B.J. \& Turón X. 2018a. Ascidiacea World Database. Ascidiacea. Available from http://www.marinespecies.org/ aphia.php? $\mathrm{p}=$ taxdetails\&id $=1839 \quad$ [accessed 13 Feb. 2018].

Shenkar N., Gittenberger A., Lambert G., Ruis M., Moreira Da Rocha R., Swalla B.J. \& Turón X. 2018b. Ascidiacea World Database. Aplidium flavum Huitfeld-Kaas, 1896. Available from http://www.marinespecies.org/aphia. php? $\mathrm{p}=$ taxdetails\&id $=251958$ [accesed 13 Feb. 2018].

Shenkar N., Gittenberger A., Lambert G., Ruis M., Moreira Da Rocha R., Swalla B.J. \& Turón X. 2018c. Ascidiacea World Database. Styela flava Herdman, 1881. Available from http://www.marinespecies. org/aphia.php? $p=$ taxdetails\&id $=253901$ [accessed 13 Feb. 2018].

Skinner L.F., Barboza D.F. \& Rocha R.M. 2016. Rapid Assessment Survey of introduced ascidians in a region with many marinas in the southwest Atlantic Ocean, Brazil. Management of Biological Invasions 7 (1): 13-20. http://dx.doi.org/10.3391/ mbi.2016.7.1.03

Tatián M., Sahade R., Doucet M.E. \& Esnal G.B. 1998. Ascidians (Tunicata, Ascidiacea) of Potter Cove, South Shetland Islands, Antarctica. Antarctic Science 10 (2): 147-152. http://dx.doi.org/10.1017/ s0954102098000194

Tatián M., Antacli J. \& Sahade R. 2005. Ascidians (Tunicata, Ascidiacea): species distribution along the Scotia Arc. Scientia Marina 69 (2): 205-214. http://dx.doi.org/10.3989/scimar.2005.69s2205

Tatián M., Sahade R., Doucet M.E. \& Esnal G.B. 1998. Ascidians (Tunicata, Ascidiacea) of Potter Cove, South Shetland Islands, Antarctica. Antarctic Science 10 (2): 147-152. http://dx.doi.org/10.1017/ s0954102098000194

Tatián M., Schwindt E., Lagger C. \& Varela M.M. 2010. Colonization of Patagonian harbours (SW Atlantic) by invasive sea squirt (Chordata, Ascidiacea). Spixiana 3 (1): 111-117.

Tatián M., Lagger C., Demarchi M. \& Mattoni C. 2011. Molecular phylogeny endorses the relationship between carnivorous and filter-feeding tunicates (Tunicata, Ascidiacea). Zoologica Scripta 40: 603-612. http://dx.doi.org/10.1111/j.1463-6409 .2011.00493.x

Taverna A., Lagger C., Maggioni T., Reyna P., Lovrich G. \& Tatián M. 2018. Ascidian distribution provides new insights to help define the biogeographic provinces in the South American Region. Polar Biology 1-9. https://doi.org/10.1007/s00300-018-2272-y

Toledo F.A.L., Cachão M., Costa K.B. \& Pivel M.A.G. 2007. Planktonic foraminifera, calcareous nannoplakton and ascidian variations during the last 25 kyr in the Southwestern Atlantic: A paleoproductivity signature? Marine Micropaleontology 64: 6779. https://doi.org/10.1016/j.marmicro.2007.03.001

Traustedt M.P. 1882. Ventindiske Ascidiae simplices. Først Afd. (Phallusidae). Videnskabeli Meddelelser fra den Naturhistoris Forening $i$ Kjöbenhaven 1881: 257-288.

Turon X., Cañete J.I., Sellanes J., Rocha R.M. \& López-Legentil S. 2016. Ascidiafauna (Tunicata, Ascidiacea) of subantarctic and temperate regions of Chile. Zootaxa 4093 (2): 151-180.

Varela M.M. 2007. Contribución al conocimiento de las ascidias coloniales (Chordata, Tunicata) de la Antártida occidental y Región Magallánica. PhD thesis, Departamento de Ciencias del Mar y Biología Aplicada, Universidad de Alicante, España.

Van Name, W.G. 1945. The North and South American Ascidians. In: Tyler, R. (ed). Vol. 84. Bulletin of the American Museum of Natural History. New York.

Vinogradova N.G. 1969. On the finding of a new aberrant ascidian in the ultra-abyssal in the KurileKamchatka Trench. Byulleten Moskovskogo Obshchestva Ispytatelej Prirody, Seria Biologicheskaya 74 (3): 27-43.

Yund P.O., Collins C., Johnson S.L. 2015. Evidence of a native northwest Atlantic COI haplotype clade in the cryptogenic colonial ascidian Botryllus schlosseri. The Biological Bulletin 228 (3): 201-216.

Doi: 10.22179/REVMACN.20.589

Recibido: 26-VI-2018

Aceptado: 13-XI-2018 